\title{
LEARNING IN LATE ADULTHOOD IN THE LIGHT OF BIOGRAPHICAL RESEARCH
}

\author{
ALEKSANDRA MARCINKIEWICZ-WILK \\ Faculty of Pedagogy, University of Wroclaw, \\ Dawida 1, Wrocław, Poland \\ E-mail address: aleksandra.marcinkiewicz-wilk@uwr.edu.pl \\ ORCID: https://orcid.org/0000-0001-8016-6884
}

\begin{abstract}
Aim. The paper presents the results of research devoted to how people study in later life. The goal of research was to understand what motivates older people to participate in education. Moreover, reasons of prefering some forms of education and the importance of this aspect of previous educational experiences were studied.

Method. The method of biographical research was used. The research presented was embedded in the strand of qualitative research in an interpretative paradigm, in which cognitive science places emphasis on the subject of learners. In recruiting subjects for research intentional selection was used, based on the typical cases method. One of the basic criteria for selection of candidates was an intention to participate in education. Therefore, 12 people participated in my research -8 women and 4 men.

Results. In the biographies analysed, education proceeds in non-formal and informal areas, so both these areas merge with each other and complement each other. The return to education in late adulthood is characteristic for those biographies in which learning occurs above all in the area of non-formal education. These seniors usually undertake learning in institutions with an educational character which are aimed at that age group, such as the University of the Third Age, Seniors' Academy, or various kinds of EU trainings whose beneficiaries are older people. On the other hand, those whose biographies take the form of continued education in late adulthood realise their goals most effectively in informal education. In this area, the most frequent form of activity is self-education. This is undertaken by those who have previous knowledge of the subject, but were unable to dedicate themselves to it fully because of their professional work.

Key words: older people, learning in older age, education, adult education, non-
\end{abstract} -formal education, informal education

\section{INTRODUCTION}

$\mathrm{M}$ odern reality is characterised by constant change, unpredictability and ambiguity. Therefore, known patterns of behaviour are no longer adequate. For this reason we must know how to adjust to changing conditions 
and expectations. Such changes have their source in hitherto unprecedented technical progress, linked above all to the development of modern ICT technologies. The reason why our current community is also referred to as the young community is thatit is easier for those who have been brought up with the new technologies from a very early age to keep up with any changes.

Older people, who grew up under totally different conditions, find themselves in a more complicated situation. Lack of key competences in the use of new technologies, and decreased ability in adapting to changing conditions, may cause marginalisation and, as a consequence, social exclusion.

A factor which can level the risk of social marginalisation among the elderly is activeness. Additionally, for the elderly, having an active life-style is a condition for a positive old age (Halaweh et al., 2018). In the context of the challenges from a rapidly changing world and the development of new technologies, it appears that particularly relevant is educational activity among the elderly, due to which it is possible for them to acquire the skills and knowledge which are essential for functioning in the new reality.

\section{LEARNING FOR THE ELDERLY}

The fact that elderly people are capable of learning has already been verified by much research (Baltes \& Carstensen, 1996; Braun-Gałkowska, 2006; Coleman \&O'Hanlon, 2004; Lazarus \& Lazarus, 2006). In fact that there are differences between learning when young and later in life, such as the pace of learning and the part played by long-term and short-term memory. Nevertheless, it is important that learning is possible at this stage of life (see Wessel, Dolan, \& Hollingworth, 2018). Awareness of both of these differences is only an indicator of how the learning process should be conducted in order to be most effective for those participating in it.

Through learning, people - including the elderly - acquire new skills and develop those which they already have. Furthermore, those who are active educationally create their own educational programme, learning from life and their own experiences and those of others, as well as drawing wisdom from their relationships with their peers and the younger generation (Czerniawska, 2011, p. 52). Thanks to continuous educational activity we are able to quickly adapt, which is a constitutive characteristic of the current reality. On the other hand, due to learning we develop ourselves and widen our horizons, so activity also has a humanistic dimension. In my own solutions I define educational activeness as intentional and active participation in different types of education - formal, super-formal and informal. It is worth noting that intentionality is substantiated by the fact that "one should know how to learn, establish contact coexist with others, acquire new widely understood competences. (...) individuals must be thoroughly engaged. Purposely participate and change. Nobody will do it for them" (Czerniawska, 2011, p. 64). 


\section{ADULT MOTIVATION FOR LEARNING}

In andragogy there are three distinct factors which are connected with the motivation of adults to learn - cognitive ability, assessment of own effectiveness, and control of the learning process. The first of these is a generalisation, connected with the cognitive abilities individuals ascribe to themselves. It is the self-awareness of an individual as to whether they can cope with the given material (for example, some people do not consider themselves capable of learning a foreign language or mathematics). Self-knowledge in this field can either motivate or demotivate participation in an educational activity. The second factor refers to an assessment of one's own effectiveness. It is the conviction of an individual as to whether they are capable of learning anything at all. The more a person is convinced of their own effectiveness, the greater the effort they are able to insert to achieve their educational goals. In the case of an individual not being convinced that they "can manage", their motivation is also not high. In turn, being convinced of a high level of effectiveness provides an individual with a belief in controlling the process of education. A feeling of internal control comes when an individual considers the course of events to be the result of her/his own actions. However, when the results of a given event are perceived by an individual to be the effect of external factors over which they had no influence, we call this external control. Individuals with a sense of internal control are more determined to overcome difficulties in the process of education (Malewski, 1998, p.57).

As shown above, whether and in what form adults participate in the process of education depends on motivation. There are three categories of adults participating in education (Malewski, 1998):

- those directed by educational goals, who are characterised by an instrumental attitude to education. Their motivation is the acquisition of the competences and knowledge which make social advance possible

- those directed by participation in education, for whom educational activity is an opportunity for meeting others as a way of combatting loneliness

- those directed cognitively and developmentally, for whom learning is a deepening of the knowledge they require for their multi-dimensional development. They demonstrate a strong orientation towards the learning process itself (p. 53).

The link between age and motivation for learning among adults is noticeable. Patrycja Cross showed that young adults are characterised by a pragmatic approach to education. They treat education instrumentally, as a path to achieving their aims regarding work and social advancement. In turn, cognitive motivation is most likely to be found among those with a stabilised life and do not feel any kind of social pressure (1978, pp. 8-12). This group also includes older people, because they don't have to learn in order to get a better job or improve their social position. 
Education is an important element in the life of seniors because it is a condition for adapting to old age. It is also a relevant aspect of life-long learning (Sapia-Drewniak, 2007, pp. 116-122). According to K. P. Cross (1978, pp. 8-12), the aim of education is the preparation of an individual for life in a new dynamic and unpredictable reality. For this reason it is worth the effort in researching the ways in which seniors learn, because it may help to understand their educational needs, and then undertake activities which are aimed at the appropriate preparation of the learning process.

\section{METHODOLOGY OF OWN RESEARCH}

The aim of my research was to describe educational activeness in late adulthood. From a methodological point of view it was necessary to come up with a method of looking at a particular fragment of reality from the perspective of the individual under research. The study presented in this article was embedded in the strand of qualitative research in an interpretative paradigm. The belief in these abilities makes it possible to loosen the restrictive demands obligatory in the scientific method, and bestow the individual with subjectivity. The methodological postulate of understanding, which is expressed by consent to learning through interpretation, creates a situation of cognitive freedom. This paradigm postulates an understanding of the subjective world of the senior. In this research the biographical method was employed, in which interpretation accomplished through dialogue plays a central role (Dominicé, 2006, p. 27).

In recruiting subjects for the research intentional selection was used, based on the typical cases method. The choice of research groups depended on reaching people over 60 who were educationally active. One of the basic criteria for selection of candidates was an intention to undertake educational activity. This is also one of the factors that characterises the education of adults, as Malcolm Knowles noted, adults should be aware of the gap between competences possessed and desired, and also the need to fill that gap through learning (Knowles, Holton, \& Swanson, 2009, pp. 168-184). This criterion also allowed me to take into consideration those individuals who undertake learning through non-formal education.

In qualitative research it is difficult to establish the number of individuals. The size of the group depends on obtaining the data saturation state- a situation where the data coming from a new person does not give new information, but only duplicates the existing ones. (Kvale, 2004, p. 109). It should be remembered that selection should be guided by completeness, therefore the results should be audited according to their similarities and differences, as long as it does not reach a saturation point in which subsequent data provide neither new knowledge nor interpretation. In effect, 12 people participated in my research -8 women and 4 men. 


\section{EDUCATIONAL ACTIVENESS IN LATE ADULTHOOD - RESEARCH RESULTS}

Late adulthood is interpreted by the narrators as a period of educational development and self-fulfilment. All those under research had remained active after retirement, and their activity had been directed towards education. So what does learning among seniors look like? By analysing the education biographies of the research subjects it was possible to indicate the

Table 1

Specifics of educational activeness among the elderly

\begin{tabular}{|c|c|c|}
\hline $\begin{array}{l}\text { Form of education } \\
\text { (P. H. Coombs) }\end{array}$ & Non-formal education & Informal education \\
\hline Line of education & $\begin{array}{l}\text { Returning line of education in } \\
\text { late adulthood }\end{array}$ & $\begin{array}{l}\text { Continuing line of education } \\
\text { in late adulthood }\end{array}$ \\
\hline $\begin{array}{l}\text { Place (area) of } \\
\text { learning }\end{array}$ & $\begin{array}{l}\text { Educational institutions } \\
\text { - University of the Third Age } \\
\text { - Educational institutions } \\
\text { offering courses and training for } \\
\text { seniors }\end{array}$ & $\begin{array}{l}\text { - self-education } \\
\text { - non-educational institutions } \\
\text { - learning from everyday life }\end{array}$ \\
\hline $\begin{array}{l}\text { Forms of } \\
\text { educational activity }\end{array}$ & $\begin{array}{l}\text { - foreign language courses } \\
\text { - computer and ICT courses } \\
\text { - courses and training in self- } \\
\text { development } \\
\text { - workshops and courses in } \\
\text { art (choirs, painting, dancing, } \\
\text { musical theatre) } \\
\text { - lectures and readings on } \\
\text { a wide range of topics (e.g. } \\
\text { gerontology, philosophy, } \\
\text { religion, health, physics) }\end{array}$ & $\begin{array}{l}\text { - reading } \\
\text { - "surfing" the Internet } \\
\text { in search of information } \\
\text { interesting to seniors } \\
\text { - reflective observation of the } \\
\text { surrounding world } \\
\text { - learning from others and the } \\
\text { experiences of others }\end{array}$ \\
\hline $\begin{array}{l}\text { Reasons for } \\
\text { preferring this } \\
\text { form of educational } \\
\text { activeness }\end{array}$ & $\begin{array}{l}\text { - need for external motivation } \\
\text { to learn } \\
\text { - trainer / teacher is an } \\
\text { important person in the learning } \\
\text { process for seniors } \\
\text { - need to form relationships } \\
\text { with others } \\
\text { - possibility of choosing from } \\
\text { previously prepared education } \\
\text { proposals }\end{array}$ & $\begin{array}{l}\text { - freedom and independence } \\
\text { in choosing learning content, } \\
\text { time and place } \\
\text { - strong internal motivation } \\
\text { to learn } \\
\text { - need to focus on oneself and } \\
\text { own educational development }\end{array}$ \\
\hline Purpose of learning & $\begin{array}{l}\text { Learning new things such as: } \\
\text { - becoming familiar with new } \\
\text { content } \\
\text { - acquiring practical skills }\end{array}$ & $\begin{array}{l}\text { - Broadening knowledge in } \\
\text { already familiar subjects } \\
\text { - content is uncomplicated } \\
\text { and easily accessible, so the } \\
\text { support of a teacher is not } \\
\text { essential }\end{array}$ \\
\hline $\begin{array}{l}\text { Characteristics } \\
\text { of the learning } \\
\text { process for seniors }\end{array}$ & \multicolumn{2}{|c|}{$\begin{array}{l}\text { Learning as a subject in the education process } \\
\text { Taking responsibility for own education } \\
\text { Possibility to influence the learning process and its content }\end{array}$} \\
\hline
\end{tabular}


forms of education in which seniors undertake educational activity most often.

Learning among the elderly does not normally appear in the range of formal education, because by its very premise it applies above all to the education of children, youth and young adults (formal education embraces the steps in education from primary school up to and including doctoral studies). Obviously, older people can undertake higher or doctoral studies, but there was no case of this among the subjects.

In the biographies analysed, education proceeds in both non-formal and informal areas, so both these areas merge with each other and complement each other. The division presented in Table 1 is arbitrary and its purpose is to indicate certain proprieties concerning learning among the elderly. It should be noted that in each educational biography a dominant field of education, in which seniors realise their educational activity, is apparent. It is interesting that often the domination of one of the areas of educational activity is analogous to a specific line of educational development among seniors, either continuation or return.

\section{SENIORS LEARNING IN THE AREA OF NON-FORMAL EDUCATION}

The return line of education in late adulthood is characteristic for those biographies in which learning occurs above all in the area of non-formal education. These seniors usually undertake learning in institutions with an educational character which are aimed at that age group, such as the University of the Third Age, Seniors' Academy, or various kinds of EU training whose beneficiaries are older people. These institutions offer prepared education programmes from which seniors can choose lessons which interest them. It transpires from the narratives that the research subjects most often learn foreign languages (especially English), use of computers and the Internet, and participate in seminars where issues concerning gerontological prophylactics are raised. Similar research results concerning the education preferences of seniors were obtained by Beata Ziębińska (2010, pp. 280-287).

Particularly important for seniors is deepening their knowledge in the field of culture, as well as participating in it. During the narratives they frequently emphasised that it was not until their retirement thatthey found time to broaden their knowledge in this field, and also to test their abilities (participation in choirs, painting, photography, and theatrical projects). Many narrators emphasised that they felt a natural internal need for communion with art in its widest sense. Activities in this area are not directed at acquiring competences which are useful in the modern world, but for them they have a transcendental dimension. Due to experiencing and creating art, the subjects develop as human beings. Here there is a visible link 
with the theory of self-actualisation, according to which individuals naturally aspire to realise their own potential, and develop their own skills and possibilities (Janowska, 1994, p. 84).

It is interesting that in the opinion of the narrators, the possibility of choosing lessons from a prepared syllabus was an asset in this type of learning, and this was often emphasised in the narratives:

I came to the U3A because there was a wide range of possibilities. If one didn't suit me I went to another, and that was interesting. If I could, I would go to all of the lessons, but they overlap (Jan - narrator 1).

I like dancing lessons the most. I also learn foreign languages - English from the beginning and also German, which I knew earlier and am now continuing. Apart from this I also go to philosophy and gerontology, and other lectures if they are interesting (Danuta - narrator 5).

As M. Knowles noted, when adults are learning they want to have an influence over what and when they learn (Knowles, Holton, \& Swanson, 2009, pp. 168-184). This is also the same situation among elderly students. The possibility of choosing the topic, length of lessons and the teacher is for them very important, because it gives them a feeling of guiding their own development. In the opinion of those questioned, the teacher has a particular significance in the choice of educational activity, because the teacher directs the learning process and motivates the seniors to learn:

I like learning when I'm dealing with a master. But a master whom I consider as a master - I have one now. Then I can read or listen, without analysing whether it's good for me or not (...) I don't always have to accept everything as my own, but I like to acquaint myself with new perspectives (...) (Vera - narrator 9).

The course format suits me best, because when I'm interested in a particular topic I register for a course in it and then develop my knowledge of it. I'm not the type who can force myself to work - I need somebody to hang over me, and then I'm motivated (Janina - Narrator 2).

The replies above prove that, by having an influence over the participation of seniors in education, the teacher is an important element. Interesting is the fact that elderly people do not want to play the role of a passive pupil, but expect a partner relationship. During the interviews, the research subjects were not uncritical of the lessons they participate in. They were able to indicate those elements which they liked, and those which should be changed. This is evidence that they want to have a real influence over their own education process:

(...) It needs to be a little more diversified, because many people are a little discouraged by this psychology. Too much of only mind gymnastics, because these exercises are not exactly what we will use in life-according to me it's just a kind of game. In my opinion there should be lessons on negotiation, assertiveness and communication. We had them once and they were very interesting. I think they would be more useful for us (Lucyna - narrator 7).

I always insisted on the scientific character of our U3A - that it should be not only interest groups but also the possibility of sharing knowledge and getting to 
know new things. Now, to a small degree, I consider that the intellectual aspect of this U3A is visible, because practical lessons predominate. There are too few lessons connected with knowledge (Vera - narrator 9).

Another factor which makes seniors want to learn in non-formal education institutes is the need to have contact with others. As shown by various research projects, elderly people often feel lonely. Activeness, including educational, averts loneliness and isolation among the elderly ${ }^{13}$. On the one hand participation in group activities develops them from a cognitive point of view, but it also creates the possibility of making new friends and satisfying the need for affiliation. This aspect also appeared in the narratives:

After my wife died I became depressed, and the U3A was meant to be a steppingstone to other people (Przemysław - narrator 4).

(...) I miss such companionship in education, because I have had such friends for many years but they all have families (Katarzyna - narrator 12).

Educational activity in the sphere of non-formal education is first and foremost realised in situations in whiche the seniors are learning subjects which were hitherto unknown to them. The cognitive sphere is difficult, to the extent that the presence of a teacher is necessary to guide the learning process (e.g. foreign languages, computer use, gerontology). This type of learning concerns most of those narrators who represent the returning line of education in late adulthood. Therefore they are those who undertake education in their retirement in the areas hitherto unknown to them, such as Janina (narrator 2), Jan (narrator 1) and Marcin (narrator 3).

\section{SENIORS LEARNING IN THE AREA OF INFORMAL EDUCATION}

On the other hand, those whose biographies take the form of continued education in late adulthood realise their goals most effectively in informal education. In this area, the most frequent form of activity is self-education. This is undertaken by those who have a previous knowledge of the subject, but were unable to dedicate themselves to it fully because of their professional work. An example of this is Jerzy (narrator 11), who could not engage fully in his passion (genealogy) until after his retirement:

If you have a passion, you repeat to yourself that when you retire you will devote yourself to it. And that is precisely my case, because now I have time to engage in genealogy (...) I was infected with genealogy by my father when I was a child, except that I didn't have time to take it up seriously. All my life I worked in two and a half jobs at the same time - it was something normal for me (...).

There was a similar situation in the case of Joanna (narrator 6), a doctor, who in retirement is broadening her interest in natural medicine:

If something is very interesting to me I buy books, search the Internet and read. Recently I have been buying books on natural medicine, homeopathy, herbal remedies and so on. So if I am very interested in something I try to get to it, looking everywhere I possibly can. 
The narrators quoted above already had some knowledge in the area of their educational activity, and after retirement they are simply broadening it. Of course, they do not restrict themselves only to self-education and continuing their earlier interests. They are also open to new educational activities and undertake learning in other areas, while their biographies are dominated by activities connected with their earlier passion.

Self-education is undertaken by those with a strong internal motivation to learn and don't need an external stimulus. The advantage of this type of learning, as indicated by the seniors, is that they themselves decide the subject, time and ways of learning.

Learning through self-education is not restricted to deepening an earlier passion. Many narrators take up self-learning in areas where knowledge is easily accessible and the support of a teacher is not necessary to understand content or to master skills. Very common educational activities among seniors are reading and searching for knowledge with the help of the Internet. However, broadening knowledge in this way applies the fields of art, travel (meeting new cultures, learning the history of places visited), philosophy, etc. All the narrators had practiced self-education (reading), while only a handful of them indicated that it was their only (Katarzyna, narrator 12) or main educational activity (Vera, narrator 9; Hanna, narrator 10).

The seniors also pointed to learning from everyday life in their narratives, which is understood by them as gaining experience, reflection and criticism of the reality surrounding them, as well as learning from the experiences of their own and others :

Life itself teaches the most, but only if we want to learn. We learn if we are able to draw conclusions from a given situation, however difficult. However, if we look upon the situation from the perspective of someone complaining that such a thing had happened, without any analysis, then we learn nothing. We should know how to learn (Vera - narrator 9).

An area of learning which frequently appeared in the narratives was travel (narrators 3, 5, 6, 10, 11, 12). Travel motivated them to broaden their knowledge concerning the places they visited, their history and culture: Travel allows us to understand other people and broadens our horizons (Hanna - narrator 10). This activity also allows us to confront previously acquired knowledge with reality. It is also an opportunity to test language skills: I even made some progress with Spanish. We went to Spain and I was able to make myself understood when the toilet flush in my room broke. In the event I managed to communicate and that was my success (Marcin - narrator 3).

I learn languages because I travel a lot so they come in useful. I've been in Thailand and Mexico. I like Thailand most of all, it's so colourful, the people are very friendly and the food is something else. I'm inspired to travel because I'm curious about the world. Somebody once told me that travel educates the educated, because if (let's say) uneducated people travel they are not even able to notice what's around them. People often want to brag that they've been here and there, but they don't understand the significances and the history, they quite simply don't realise where they are. (...) Before travelling I always prepare myself by reading (Danuta - narrator 5). 
Educational activeness of seniors in the field of informal learning refers above all to self-education. It is an activity that is undertaken in a well-thought-out and systematic way. Furthermore, within the framework of this form of education there is also learning from everyday life, including learning from the experiences of others and also through encounters (travelling).

\section{THE FUNCTIONS OF EDUCATIONAL ACTIVENESS IN LATE ADULTHOOD}

The characteristic of the two forms of learning which describe the educational activeness of seniors is somewhat arbitrary, because learning is most often undertaken by seniors in both areas, which overlap and complement each other.

It is worth emphasising that in all of the biographies analysed in this research, education is a value and holds an important place in their lives. The biographies show that it is possible to indicate at least three meanings given by the narrators. These meanings define the functions which are attributed to learning by the research subjects themselves:

- learning as an activity broadening horizons and enabling self-development - self-development function

- learning as an activity replacing work - compensation function

- learning as an activity allowing participation in social life - participating function

The function of participating refers to the functioning of an individual in society, therefore learning should help the individual in her/his participation in social life. This confirms that on the one hand learning is meant to give an individual a place in society, but on the other hand, it is also to provide a chance to develop individual abilities, which corresponds to the self-development function.

It is interesting that the narrators themselves more often emphasised in their narratives that learning is a value in itself and is always good for the development of an individual:

(...) it is something which leads to some kind of development, independent of its form, but everything leads to our mind developing, our body developing, and we are more emotional and mature - education is for me all of these things (Danuta - narrator 2).

Learning is more comprehensive. It allows us to better understand our identity. I can also bring out more from outside than what is inside me. Apart from this it allows me to better to understand others and reach out to them (Joanna - narrator 6).

Learning is above all studying, and therefore discovery. It should be the road for us, because it is precisely investigation and discovery which give us such joy and satisfaction. I myself see a need among people for learning, and that seems to me to be good (Grażyna - narrator 8). 
Learning in a humanistic dimension, so one which is focussed on their self-development, was appeared very frequently in the narratives. This could be treated as a return to subjectivity among those who are learning, and learning should above all serve the individual and her/his self-realisation. This refers to the theory of self-actualisation, the essence of which is the continual pursuit of individuals to realise their potential and develop their skills and abilities.

As already noted, retirement was a kind of milestone in education among those who were researched. For many retirement is the longed-for time when they can devote themselves to their passion. In turn, for many it means the conclusion of an important period in their life and is interpreted as a critical event. Education became a kind of alternative for their professional life.

It turned out that I suddenly went into retirement, and I had much more time on my hands, so what to do with it? It was a shock because I didn't want to retire. They told me it was time to go. Farewell was very painful. I realised that now I could do something just for myself. I joined the adult Art Academy, which was connected with my earlier plans (...) (Hanna - Narrator 10).

Educational activeness appears in the narratives as a certain inevitability. As the narrators define, those who are not learning are excluded from society. Therefore a condition for participation in social life is participation in education, which is reflected in the following answers:

Learning allows us to live much better in our world. Somebody who does not know how to learn becomes marginalised (Jan - narrator 1).

Above all, learning is the most important in our society. If you don't have the need to learn inside you, you are condemned to be marginalised, because the world is always driving forward because that means development. If I reject development from the beginning, because I don't want to learn anything, I am condemned to being marginalised. It seems to me that, irrespective of social model, there is always some vanguard which drives forward, dragging the masses behind them, and in the end a kind of cosmic dust remains, composed of those who failed to keep up (Vera - narrator 9).

Here it is worth referring to research into the position of the elderly in relation to education, conducted by Magdalena Pakuła (2010, pp. 34-39). That research was done as part of a quantitative strategy using the method of a diagnostic survey. Most of those researched (71.3\%) indicated that education constitutes a significant life value. Furthermore, the quantitative research showed that the more educated the respondents were, the higher they valued education. Apart from this, a significant number of seniors perceive the benefits flowing for education in late adulthood. $40.7 \%$ of respondents consider that learning makes it easier to cope with everyday problems, and $21.2 \%$ of them are of the opinion that participation in education satisfies their interests and makes for a more interesting life (Pakuła, 2010, pp. 98-106). M. Pakuła's results clearly correspond to the conclusions of the research presented here. However, a fundamental difference 
between them can be noticed. The quantitative research showed that although the majority of elderly people acknowledge that education is an important life value, only a small number of them participate in education in late adulthood. The knowledge and convictions of those researched on the subject of the value of education in relation to their attitudes does not form a consistent pattern. A divergence between declared judgements and their behaviour is visible, because only $5.8 \%$ of people were educationally active. This difference results from the fact that the quantitative research referred to a group of seniors in general. On the other hand, the present research focusses on seniors who are educationally active, and who, as M. Pakuła's research shows, form a specific group (see Kim \& Merriam, 2004; Boulton-Lewis, Buys, \& Lovie-Kitchin, 2006). It is, however, essential that learning should be an important life value for all elderly people, not just those who are educationally active.

In their narratives, the seniors who participated in the present research often emphasised that learning is not only a value in itself, but also forms an important element of participation in social life. A rapidly changing world confronts them with many challenges which they are able to cope with due to participation in education. Therefore, learning is a road to their self-realisation, which is apparent in a return of interests towards art and culture. It is also an activity whose aim is to combat social exclusion among the elderly. Those who participated in the research realise the important role played by education, and confirmation of this is found in their narratives.

\section{CONCLUSIONS}

Two fundamental paths to the educational development of seniors were revealed in the biographies analysed. One of them concerns the continuation of earlier education interests in old age, and is connected with informal education. On the other hand, the second one shows a return to education during retirement, and most frequently takes place within the framework of non-formal education, in educational institutions.

Analysis of the data also shows that in preparing a syllabus for the elderly, the specifics of learning in this social group should be taken into consideration. It is possible to differentiate between the two types of education which older adults prefer - non-formal and informal. Non-formal learning mainly takes place in institutions specifically directed towards the elderly (such as the University of the Third Age), and concerns above all the acquisition of previously unknown knowledge and skills. In this respect specialist support from a teacher or trainer is required. It should be noted that this form of education is preferred by those who need external motivation to learn, either from the teacher or the group.

On the other hand, informal education concerns above all self-education as well as learning from everyday life. This type of educational activity is char- 
acteristic for those who have already realised themselves educationally in a chosen field at an earlier stage in life. Late adulthood, without professional activity, allows the possibility of fuller dedication to interests which had been awakened earlier in life. Older people who prefer this kind of study do not need a teacher who will provide them with content, but a partner who is able to explore their interests with them. It is worth emphasising that a teacher in the traditional meaning is not needed by seniors learning this way, because they are already sufficiently conversant with their areas of interest that they could be teachers for others. In this context it is worth considering the possibility of engaging seniors in this group to take on the role of a tutor or mentor. In such a way their potential can be used to teach or inspire others. Moreover, the role of mentor provides another perspective and inclines to deeper reflection, and thus stimulates the learning process.

It should be noted that similar conclusions to the results of my research were reached by Jenes Friebe and Bernhard Schmidt-Hertha who underline that "educational activities for the elderly are highly dependent on their different biographical and social circumstances. Educational interests and learning attitudes are affected by early educational experiences gained in school or during vocational training and by previous adult education activities" (2013, p. 13).

It should be stressed that for both these approaches is the importance of retaining subjectivity, therefore the education process for seniors should be so designed so as consider the subjectivity of the students. It is important that seniors should have a sense of influence on the course of the learning process, because they know best what they need and the way in which they want to absorb knowledge.

\section{REFERENCES}

[1] Baltes, M. M., Carstensen, L. L. (1996). The process of successful aging. Aging and Society, 16, 397-422.

[2] Braun-Gałkowska, M. (2006). Nowe role społeczne ludzi starych [New social roles of older people]. In: S. Steuden, M. Marczuk (Eds.), Starzenie się a satysfakcja życia [Ageing and life satisfaction] (pp. 183-195). Lublin: Wydawnictwo KUL.

[3] Coleman, P. G., O'Hanlon, A. (2004). Aging and Development: Theories and Research. London: Hodder Education Publishers.

[4] Cross P., Though A., Weathersby, R. (1978). The Adult Learner. Current issues in higher education. Washington: American Association for higher education.

[5] Czerniawska, O. (2011). Nowe drogi w andragogice i gerontologii [New ways in andragogy and gerontology]. Łódź: Wydawnictwo Akademii Humanistyczno-Ekonomiczne.

[6] Dominicé, P. (2006). Uczyć się z życia. Biografia edukacyjna w edukacji dorostych [To learn from life. Educational biography in adult education]. Łódź: Wydawnictwo Wyższej Szkoły Humanistyczno-Ekonomicznej.

[7] Boulton-Lewis, G. M., Buys, L., Lovie-Kitchin, J. (2006). Learning and Active Aging. Educational Gerontology, 32:4, 271-282, DOI: 10.1080/03601270500494030

[8] Friebe, J., Schmidt-Hertha, B. (2013). Activities and barriers to education for elderly people. Journal of contemporary educational studies, 1, 10-26.

[9] Halaweh, H., Dahlin-Ivanoff, S., Svantesson, U., Willén, C. (2018). Perspectives of Older Adults on Aging Well: AFocus GroupStudy. Journal ofaging research,https://doi.org/10.1155/2018/9858252. 
[10] Janowska, J. (1994). Psychologia humanistyczna jako podstawa praktyki pedagogicznej [Humanistic psychology as a basis for pedagogical practice]. In: M. Łobocki (Ed.), Psychologia humanistyczna a wychowanie [Humanistic psychology and education]. Lublin: Wydawnictwo UMCS.

[11] Kim, A., Merriam, S. B. (2004). Motivations for learning among older adults in a learning in retirement institute. Educational Gerontology, 30:6, 441-455, DOI: 10.1080/03601270490445069.

[12] Knowles, M., Holton III, E. F., Swanson R. A. (2009). Edukacja dorostych: podręcznik akademicki [Adult education: academic textbook].Warszawa: PWN.

[13] Kvale, S. (2004). Wprowadzenie do jakościowego wywiadu badawczego [Introduction to qualitative research interview]. Białystok: Trans Humana.

[14] Lazarus, R. S., Lazarus, B. N. (2006). Coping with aging. Oxford: University Press.

[15] Malewski, M. (1998). Teorie andragogiczne: Metodologia teoretyczności dyscypliny naukowej [Andragogical theories: methodology of theoreticality of a scientific discipline]. Wrocław: Wydawnictwo Uniwersytetu Wrocławskiego.

[16] Pakuła, M. (2010). Postawy osób starszych wobec edukacji: studium teoretyczno-diagnostyczne [Attitudes of older people towards education: theoretical and diagnostic study]. Lublin: Wydawnictwo UMCS.

[17] Sapia-Drewniak, E. (2007). Kreatywna rola uczenia sie w procesie rozwoju cztowieka starszego [The creative role of learning in the development of the elderly]. In: S. Rogala (Ed.), Wybrane problemy procesu starzenia się człowiek [Selected problems of the human aging proces]. Opole: Wydawnictwo Instytut Śląski.

[18] Wessel, J. R., Dolan, K.A., Hollingworth, A. (2018). A blunted phasic autonomic response to errors indexes age-related deficits in error awareness. Neurobiology of Aging, 71 (13), DOI: 10.1016/j.neurobiolaging.2018.06.019.

[19] Ziębińska, B. (2009). Uniwersytety Trzeciego Wieku jako instytucje przeciwdziałające marginalizacji osób starszych [Universities of the Third Age as institutions preventing the marginalisation of older people]. Katowice: Wydawnictwo Naukowe „Śląsk”. 